\title{
Type II gonadotrophin-releasing hormone (GnRH-II) in reproductive biology
}

\author{
Adam J. Pawson, Kevin Morgan, Stuart R. Maudsley and Robert P. Millar* \\ Human Reproductive Sciences Unit, Medical Research Council, Edinburgh EH16 4SB, UK
}

\begin{abstract}
Humans may be particularly unusual with respect to the gonadotrophin-releasing hormone $(\mathrm{GnRH})$ control of their reproductive axis in that they possess two distinct $\mathrm{GnRH}$ precursor genes, on chromosomes 8p11-p21 and 20p13, but only one conventional GnRH receptor subtype (type I GnRH receptor) encoded within the genome, on chromosome 4. A disrupted human type II GnRH receptor gene homologue is present on chromosome 1q12. The genes encoding GnRH ligand precursors and GnRH receptors have now been characterized in a broad range of vertebrate species, including fish, amphibians and mammals. Ligand precursors and receptors can be categorized into three phylogenetic families. Members of each family exist in primitive vertebrates, whereas mammals exhibit selective loss of ligand precursor and receptor genes. One interpretation of these findings is that each ligand-cognate receptor family may have evolved to fulfil a separate function in reproductive physiology and that species-specific gene inactivation, modification or loss may have occurred during evolution when particular roles have become obsolete or subject to regulation by a different biochemical pathway. Evidence in support of this concept is available following the characterization of the chromosomal loci encoding the human type II GnRH receptor homologue, a rat type II GnRH receptor gene remnant (on rat chromosome 18) and a mouse type II GnRH ligand precursor gene remnant (on mouse chromosome 2). Whether type I GnRH and type II GnRH peptides elicit different signalling responses in humans by activation of the type I GnRH receptor in a cell type-specific fashion remains to be shown. Recent structure-function studies of GnRH ligands and $\mathrm{GnRH}$ receptors and their expression patterns in different tissues add further intrigue to this hypothesis by indicating novel roles for $\mathrm{GnRH}$ such as neuromodulation of reproductive function and direct regulation of peripheral reproductive tissues. Surprises concerning the complexities of $\mathrm{GnRH}$ ligand and receptor function in reproductive endocrinology should continue to emerge in the future.
\end{abstract}

Gonadotrophin-releasing hormone $(\mathrm{GnRH})$ plays a pivotal role in the regulation of reproduction by stimulating release of $\mathrm{LH}$ and $\mathrm{FSH}$ from the anterior pituitary. The $\mathrm{GnRH}$ system has been analysed in a large number of different species with a view towards developing therapies for pathological conditions and for methods to assist reproduction. In excess of 1000 scientific publications per year indicate that the comprehensive role of $\mathrm{GnRH}$ in reproductive biology, although incompletely understood, remains of considerable therapeutic interest. Information is accumulating in several fields of investigation, including molecular genetics, gene expression, receptor structure-function and reproductive pathophysiology.

${ }^{*}$ Correspondence

Email: r.millar@hrsu.mrc.ac.uk
Recent advances are summarized in the following sections.

\section{The prepro-GnRH-II and type II GnRH receptor genes}

The prepro-GnRH-II gene consists of a $5^{\prime}$-untranslated exon and three coding exons, with the mature peptide encoded within coding exon 1 (White et al., 1998). This gene lies in close proximity to two flanking genes. A recent study examining human prepro-GnRH-II gene regulation identified multiple regulatory elements within the untranslated exon 1 of the gene, including two putative E-box binding sites which function cooperatively to stimulate the basal transcription of the gene. It was also demonstrated that the transcription factor AP-4 is an enhancer protein for the $\mathrm{GnRH}-\mathrm{II}$ 


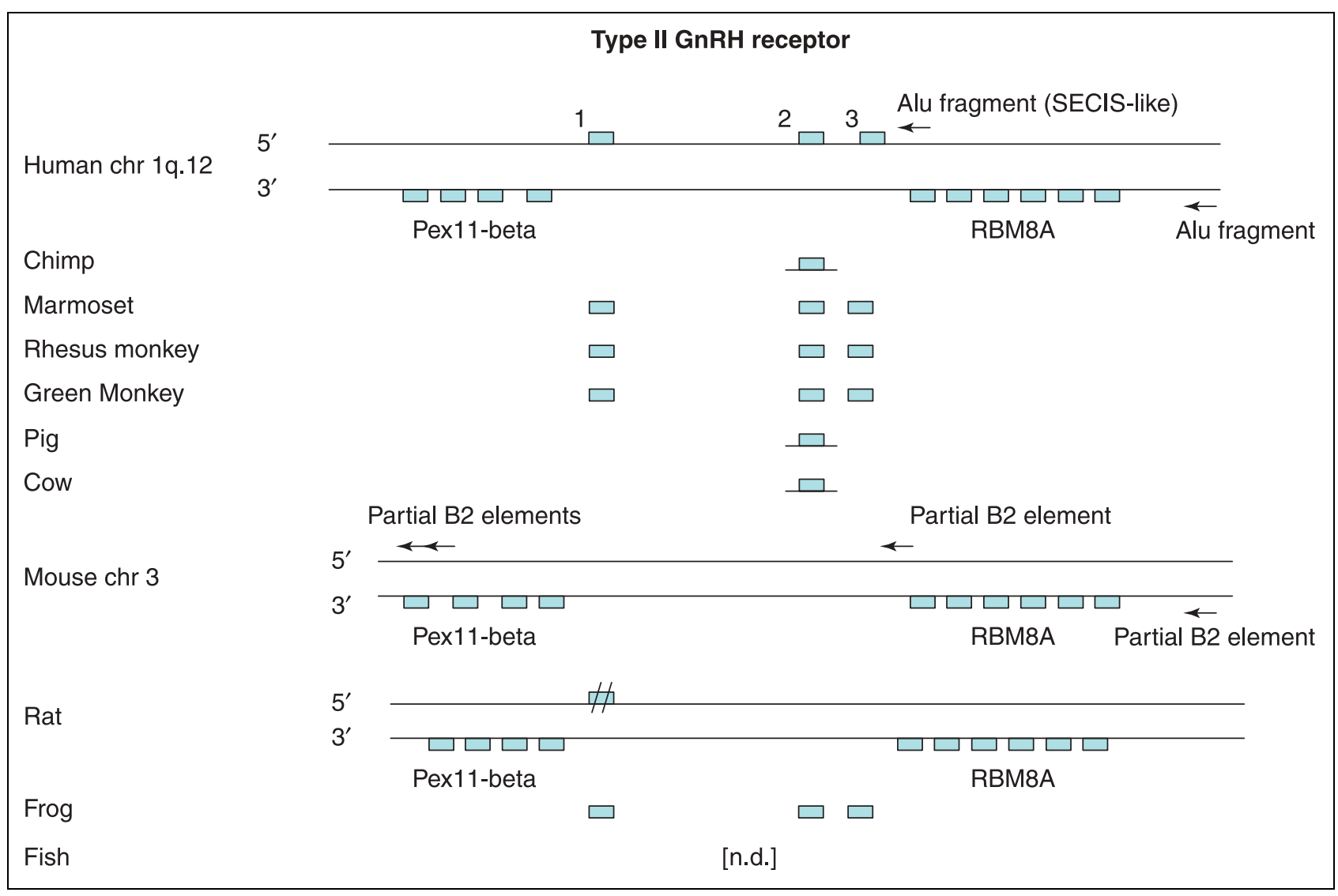

Fig. 1. Current status of type II gonadotrophin-releasing hormone $(\mathrm{GnRH})$ receptor gene characterization in a range of species. Solid lines indicate DNA strands and boxes indicate positions of coding exons. (GenBank accession numbers: human genomic DNA AL160282, chimp genomic DNA AG122659, marmoset cDNA AF368286, rhesus monkey cDNA AF353987, green monkey cDNA AF353988, pig genomic DNA BF702918, cow genomic DNA AV604131, mouse genomic DNA AC122037, rat genomic DNA AC106482 and bullfrog cDNA AF144062.) Remnants of coding sequences are depicted as slashed boxes. Distribution of selected repetitive sequence elements (human Alu and mouse B2) is indicated (arrows denote orientation). n.d.: Not determined; Pex11-beta: gene for peroxisomal protein $11 \beta$ (GenBank accession number AB018080); RBM8A: RNA binding motif protein 8A (GenBank accession number AF231511); SECIS: selenocysteine insertion sequence.

promoter (Cheng et al., 2003). The function of the carboxyl-terminal domain of the precursor molecule remains unknown but it is possibly involved in packaging the hormone into storage vesicles or it may produce processed peptides with unknown regulatory functions such as that postulated for the $\mathrm{GnRH}$-associated peptide (GAP) of the prepro-GnRH-I gene (Chavali et al., 1997). The mammalian type II GnRH receptor gene consists of three coding exons spanning $7.5 \mathrm{~kb}$. The human gene contains a frameshift in coding exon 1 and a premature stop codon in exon 2. The gene also overlaps two flanking genes but remains transcriptionally active and displays alternative splicing (Morgan et al., 2003).

The cDNA and genomic DNA sequences encoding $\mathrm{GnRH}-\mathrm{II}$ precursors and type II GnRH receptors have been characterized for an increasing number of vertebrate species (Millar et al., 2001; Wang et al., 2001; Bogerd et al., 2002; Okubo et al., 2002a,b). This information enables classification of ligand-precursor and receptor isoforms according to their primary structures, rather than their pharmacological properties (Millar et al., 2003).

Progress in genome sequencing projects and conservation of the arrangement of genes flanking those of the GnRH-system means that some of the latter can now be described in the context of the chromosomal loci that they occupy (Figs 1 and 2a). This information can be used to identify remnants of GnRH-II precursor and type II $\mathrm{GnRH}$ receptor coding sequences at homologous loci in the mouse and rat genomes, respectively (Fig. 2b).

\section{Silencing of GnRH-II and type II GnRH receptor genes in certain mammalian species}

Information regarding the status of prepro-GnRH-II and type II GnRH receptor genes in mammalian species is rapidly becoming more available as a result of advances in genomic informatics. The GnRH-II ligand structure 


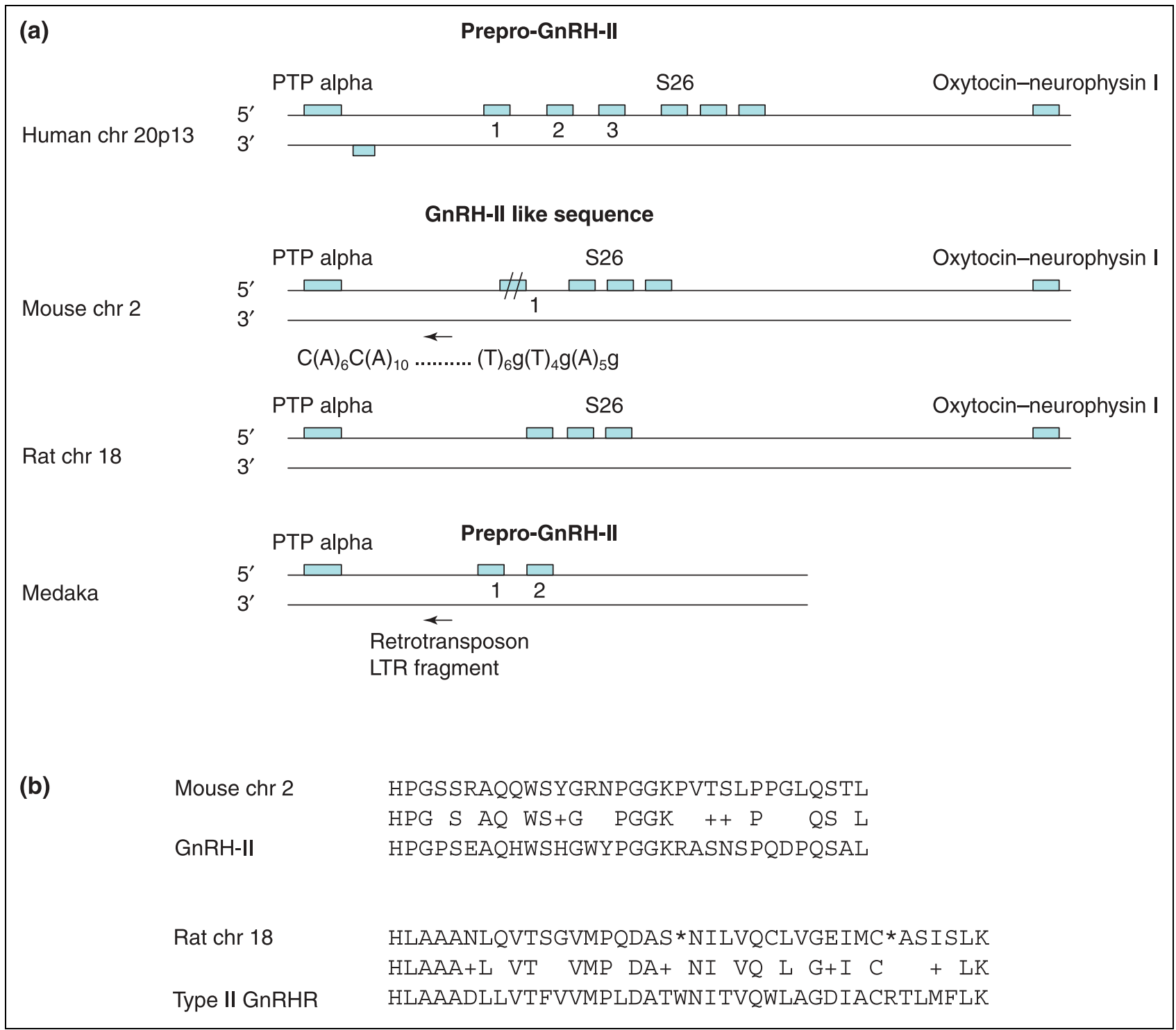

Fig. 2. (a) Current status of prepro-GnRH-Il gene characterization in human, mouse, rat and medaka. Solid lines indicate DNA strands and boxes indicate positions of coding exons. Remnants of coding sequences are depicted as slashed boxes. (GenBank accession numbers: human genomic DNA AF036329, mouse genomic DNA AL772162, rat genomic DNA AC131863, medaka genomic DNA AB074500.) PTP alpha: protein tyrosine phosphatase receptor type alpha (GenBank accession number NM_002836); S-26: mitochondrial ribosome protein S-26 (GenBank accession number BC013018); oxytocin-neurophysin I (GenBank accession number NM_000915). (b) Alignment of remnant coding sequences for mouse GnRH-II and rat type II GnRH receptor with sequences from corresponding functional genes. + represents a conserved residue; *represents an in-frame stop codon. The mouse GnRH-II precursor remnant encompasses the mature $\mathrm{GnRH}-\mathrm{Il}$ peptide-coding region. The rat type II GnRH receptor remnant encompasses transmembrane domains 2 and 3 and extracellular loop 1.

is conserved from bony fish to humans, indicating that this is probably the earliest evolved form of $\mathrm{GnRH}$ and thus has critical and specific functions. This complete conservation of structure over 500 million years indicates that $\mathrm{GnRH}-\mathrm{Il}$ has an important function and a discriminating receptor (or receptors) which has selected against any structural change in the ligand. Nevertheless, it now appears that the $\mathrm{GnRH}$-II gene has been silenced in the mouse (Fig. 2b), leaving only one functional
$\mathrm{GnRH}$ gene, the gene encoding $\mathrm{GnRH}-\mathrm{I}$. This situation is in contrast to earlier life forms, in particular fish species, which have retained three functional $\mathrm{GnRH}$ ligand subtype genes (Millar et al., 2003). Disruption or silencing of the type II receptor gene has been noted in the human and chimp (Morgan et al., 2003), cow (Millar et al., 2003), sheep (Gault et al., 2003) and rat (Fig. 2b) genomes. In contrast, marmosets (Millar et al., 2001), african green and rhesus monkeys (Neill et al., 2001) and 
Table 1. Ligand selectivity and signalling of cognate ligands at marmoset type II and human type I gonadotrophin-releasing hormone $(\mathrm{GnRH})$ receptors

\begin{tabular}{lcc}
\hline Binding and coupling & $\begin{array}{c}\text { Marmoset type II } \\
\text { receptor }\end{array}$ & $\begin{array}{c}\text { Human type I } \\
\text { receptor }\end{array}$ \\
\hline Binding & $1.0^{\mathrm{a}}$ & $0.1^{\mathrm{a}}$ \\
GnRH-II & $0.02^{\mathrm{a}}$ & 1.0 \\
GnRH-I & $0.1^{\mathrm{a}}$ & $0.1^{\mathrm{a}}$ \\
GnRH-III & Full agonist & Full antagonist \\
Antagonist 135-18 & & \\
Coupling & + & + \\
Gq/11 & + & + \\
Ca ${ }^{2+}$ & + & + \\
PKC & + (transient) & + (protracted) \\
ERK & + & + \\
p38 & Nil & + \\
JNK & Nil & + \\
C-SrC & Rapid & Slow \\
Receptor internalization & + & Nil \\
Receptor desensitization & + & \\
\hline
\end{tabular}

Type I and type II GnRH receptors exhibit distinct functional differences. Whereas the type II GnRH receptor is highly selective for binding $\mathrm{GnRH}-\mathrm{II}$, type I binds both $\mathrm{GnRHs}$ reasonably well. The type II receptor also recognizes certain type I receptor antagonists as agonists. Although cognate ligands at both receptors activate the Gq/11-inositol phosphate-Ca ${ }^{2+}$-diacylglycerol-protein kinase $\mathrm{C}$ (PKC) pathways, they exhibit distinct differences in extracellular signal-regulated kinase 1 and 2 (ERK1/2), p38 and Src activation, and in desensitization and the rate of receptor internalization.

JNK: c-Jun N-terminal kinase; c-Src: mammalian homologue v-Src of Rous sarcoma virus.

${ }^{a}$ Activities are comparative binding affinities relative to cognate ligands $\mathrm{GnRH}-\mathrm{Il}$ and $\mathrm{GnRH}-\mathrm{I}$, respectively.

pigs (Morgan et al., 2003) have retained the presence of a functional type II $\mathrm{GnRH}$ receptor. Furthermore, only fish and amphibian species have retained a functional type III $\mathrm{GnRH}$ receptor (Millar et al., 2003). The emerging picture is that the more evolved or structurally complex the species, the fewer subtypes of receptor and ligand there appear to be.

\section{Evolutionary hypotheses}

Genes encoding G protein-coupled receptors (GPCRs) are thought to have evolved by sequential gene duplication events in ancestral eukaryotic cells (Taylor and Agarwal, 1993). Retention of closely related pairs of GPCRs within the genome may have been driven by acquisition of advantageous ligand binding or signalling properties due to evolutionary drift in the coding sequences. Overlapping and distinctive properties of type I and type II GnRH receptors are listed in Table 1. Duplication and sequence divergence of genes encoding ligand precursors would also be expected to exert a significant effect on the evolutionary fate of closely related ancestral GPCRs. It is interesting to note that $\mathrm{GnRH}-\mathrm{I}$ is more positively charged (and slightly less bulky) than $\mathrm{GnRH}-\mathrm{II}$. GnRH-I is also thought to be more conformationally labile compared with the preconformed $\beta$-II turncontaining GnRH-Il (Pfleger et al., 2002; Millar et al., 2003), and perhaps these differences affecting peptide conformation have influenced $\mathrm{GnRH}$ receptor evolution (Fig. 3).

\section{Type II GnRH receptor structure-function}

The primary amino acid sequence of the marmoset type II $\mathrm{GnRH}$ receptor has $39 \%$ identity (68\% conservation) with the type I GnRH receptor. The most striking difference between the receptor subtypes is the retention of a 56 residue cytoplasmic tail domain at the carboxylterminus of the type II GnRH receptor compared with its absence in the type I receptor. The tail sequence is not conserved between mammalian and amphibian homologues. Perhaps the tail domain, encoded in exon 3 in an ancestral form of the type I receptor gene, was disrupted before a deletion event that led to the subsequent loss of the tail domain altogether. Other important sequence differences between receptor subtypes occur in the extracellular, transmembrane and cytoplasmic loop domains. The type I and type II receptor subtypes seem to differ significantly with respect to the charge distribution observed at their respective extracellular domains (Fig. 3). In type II GnRH receptors, the $\mathrm{N}$-terminal domain is two residues longer and more negatively charged than that in type I GnRH receptors. Extracellular loop 1 (ECL-1) exhibits similar charge properties in the two receptor subtypes, but ECL-2 is relatively more positively charged in type II receptors. ECL-3 is less negatively charged in the type II receptor compared with the type I receptor. Furthermore, ECL-2 and ECL-3 are shorter in the type II GnRH receptor relative to the type I receptor. The premature stop codon in the human type II receptor gene knocks out a positively charged arginine $(R)$ residue in ECL-2.

The presence of a cytoplasmic tail domain is expected to alter receptor trafficking dynamics. Indeed, a recent study demonstrated that the marmoset type II $\mathrm{GnRH}$ receptor undergoes a more rapid agonist-induced internalization compared with the human type I receptor, and the important residues within the cytoplasmic tail that are responsible for this process have been identified (K. Ronacher, C. A. Flanagan, R. P. Millar and A. A. Katz, unpublished). Furthermore, the importance of the cytoplasmic tail for rapid agonist-induced internalization has been shown for the chicken $\mathrm{GnRH}$ receptor (Pawson et al., 1998, 2003) and a number of other nonmammalian GnRH receptors (Blomenrohr et al., 1997; Lin et al., 1998; Blomenrohr et al., 1999; Heding et al., 2000; Hislop et al., 2000, 2001). The three bullfrog $\mathrm{GnRH}$ receptor subtypes display different internalization kinetics, which may be related to sequence or structural 


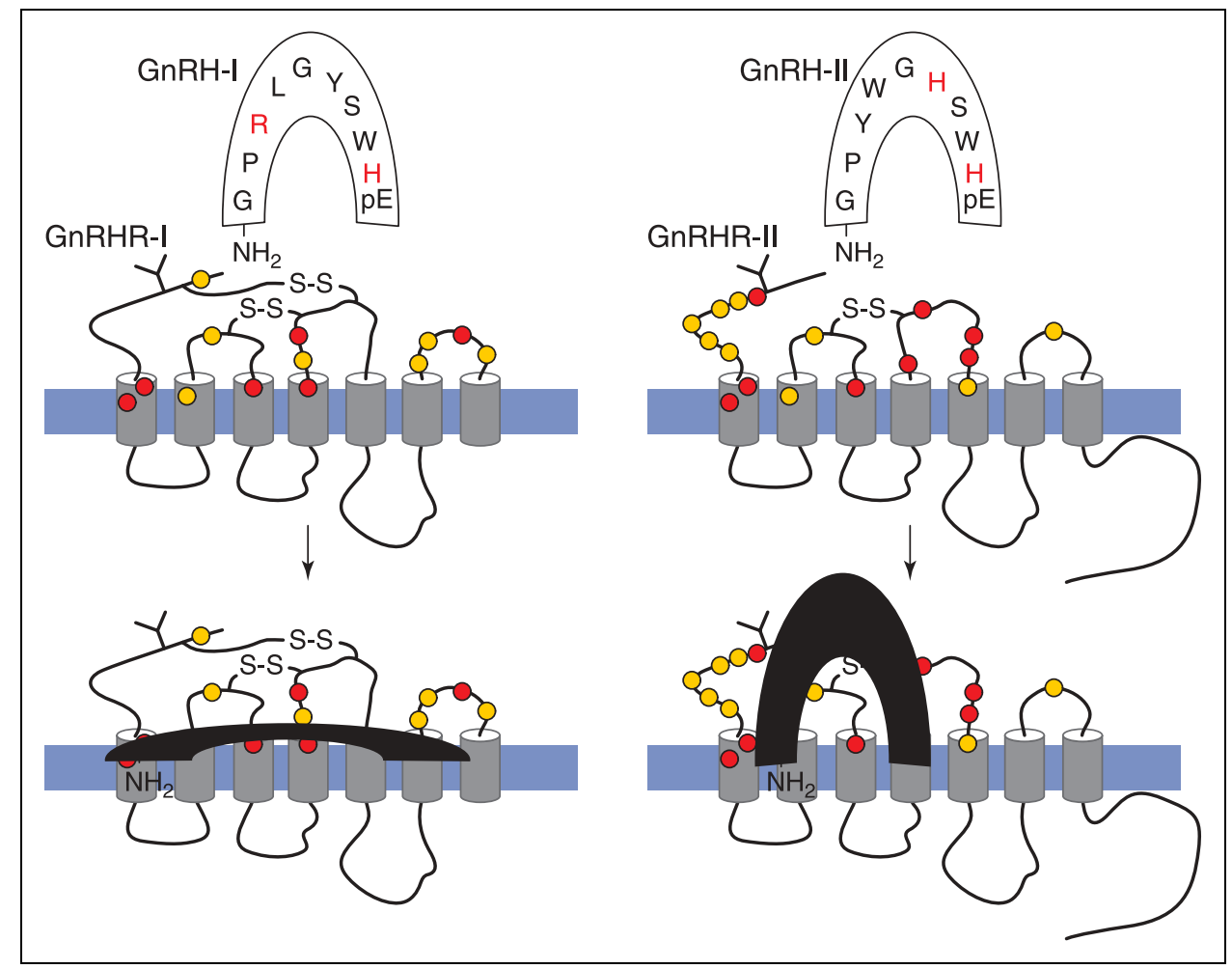

Fig. 3. Comparison of distribution of charged amino acid residues in gonadotrophin releasing hormone $(\mathrm{GnRH})-\mathrm{I}$ and $\mathrm{GnRH}-\mathrm{Il}$ peptides and in extracellular hydrophilic domains of type I and type II GnRH receptors. GnRH-I and $\mathrm{GnRH}$-II peptides are depicted here with similar conformations. Charged extracellular amino acids in the two receptor subtypes are indicated as coloured circles (yellow for negatively charged aspartate or glutamate residues, and red for positively charged arginine and lysine residues). Potential differences in the docking of the relatively conformationally labile $\mathrm{GnRH}-\mathrm{I}$ ligand and the pre-conformed GnRH-II ligand to their respective cognate receptors is emphasized in simplistic cartoon form.

motif differences in the cytoplasmic tails of these receptors (Acharjee et al., 2002).

\section{GnRH-II in reproductive pathophysiology}

GnRH-II occurs in the brain, pituitary gland, reproductive tissues and the immune system. Autocrine and paracrine roles have been hypothesized for $\mathrm{GnRH}$ in reproductive tissues but most studies have not progressed beyond preliminary characterization of gene expression (Chen et al., 1999; Cheon et al., 2001; Kang et al., 2001; Siler-Khodr and Grayson, 2001). Expression of $\mathrm{GnRH}$ receptor gene and cell-surface $\mathrm{GnRH}$ binding are very low in most extra-pituitary tissues. Furthermore, it is unclear whether $\mathrm{GnRH}$-II elicits responses in peripheral tissues that differ significantly from those caused by $\mathrm{GnRH}-\mathrm{I}$. In relation to this, the actions of GnRH-II on human placenta and baboon ovary have been investigated (Siler-Khodr and Grayson, 2001; Siler-Khodr et al., 2003). These studies proposed that $\mathrm{GnRH}-\mathrm{II}$ is a potent regulator of ovarian function and hormone regulation during pregnancy. The preconformed $\beta$-II turn conformation of GnRH-Il (Millar et al., 2003) makes this ligand more stable than GnRH-I. GnRH-II is therefore thought to be less susceptible to peptidase degradation and would therefore differ from $\mathrm{GnRH}-\mathrm{I}$ in its pharmacological bioavailability in a tissue environment (Siler-Khodr et al., 2003). Such a scenario has important implications for the role of $\mathrm{GnRH}-\mathrm{II}$, in particular for steriodogenesis and hormone regulation in reproductive tissues, and may lead to the elucidation of novel paracine roles for GnRH-II in reproductive physiology. Complex autocrine and paracrine interactions involving neurones, epithelial cells, stromal cells, stem cells and infiltrating lymphocytes can certainly be envisaged for GnRH in disorders of puberty, ovarian cycle or menstrual cycle dysfunction, idiopathic female infertility, disorders of testis and prostate gland and in neoplasia of reproductive tissues.

\section{Anti-proliferative or proliferative effects of GnRH}

The effect of $\mathrm{GnRH}$-II on human tumour cell proliferation is currently the subject of concerted investigation. It is well known that type I GnRH receptors are expressed in cancer cells, and that $\mathrm{GnRH}$ analogues can inhibit the proliferation of these cells. It appears that $\mathrm{GnRH}$ 
analogues are set to emerge as novel therapeutics in cancers expressing the type I GnRH receptor. Two recent studies have examined the signalling and antiproliferative effects mediated by GnRH receptors exogenously expressed in breast and prostate cancer cells. It was shown that the exogenous expression of type I GnRH receptors in these cells markedly enhances the antiproliferative effect of $\mathrm{GnRH}$ analogues (Everest et al., 2001; Franklin et al., 2003). These studies demonstrated that the signalling properties of the exogenously expressed receptors were functionally indistinguishable from $\mathrm{GnRH}$ receptors in pituitary gonadotropes. This result was unexpected as it is widely accepted that GPCRs in cancer cells couple predominantly through $G_{i}$ rather than their classical coupling G-protein (that is $\mathrm{G}_{\mathrm{q} / 11}$ for pituitary type I GnRH receptors), and that the pharmacology of $\mathrm{GnRH}$ analogues at tumour $\mathrm{GnRH}$ receptors is quite different from that seen at the pituitary receptor. Although the above studies focused on signalling outputs of inositol phosphate production and extracellular signalregulated kinase 2 (ERK2) phosphorylation, it is possible that a more in-depth examination of signalling events in these transfected cancer cells may reveal distinct differences. Evidence is emerging that G-protein coupling can be $\mathrm{GnRH}$-concentration dependent (Krsmanovic et al., 2003) and that downstream signalling outputs are important (Willars et al., 2001).

Why is the type I mammalian GnRH receptor so effective in inhibiting the proliferation of tumour cells? The clues to answer this question are found in studies that show that the type I GnRH receptor is resistant to desensitization, a common and rapid event in the GPCR superfamily (Davidson et al., 1994; Forrest-Owen et al., 1999), and undergoes very slow internalization compared with non-mammalian (Blomenrohr et al., 1997, 1999; Lin et al., 1998; Pawson et al., 1998, 2003; Heding et al., 2000; Hislop et al., 2000, 2001) and mammalian type II GnRH receptors (K. Ronacher, C. A. Flanagan, R. P. Millar and A. A. Katz, unpublished; Acharjee et al., 2002). Thus, the type I GnRH receptor remains active at the cell surface for longer than most other GPCRs. GnRH analogues are therefore able to bind to these receptors, leading to a protracted and eventually detrimental activation of the various signalling pathways, and the inhibition of cell proliferation. A recent study investigated the anti-proliferative effects mediated by $\mathrm{GnRH}$ receptors expressed in breast cancer cells (Finch et al., 2003). It was demonstrated that GnRH was able efficiently to inhibit proliferation via the sheep $\mathrm{GnRH}$ receptor, whereas the anti-proliferative effect was not mediated by the Xenopus type II GnRH receptor, indicating that receptor desensitization and internalization may influence the anti-proliferative effect of GnRH receptors (Finch et al., 2003).

The anti-proliferative effects of $\mathrm{GnRH}$-II have been demonstrated in human ovarian surface epithelial cells and ovarian tumours (Choi et al., 2001). The finding that the human type II GnRH receptor gene is disrupted by a frame-shift and premature stop codon indicates that a conventional type II GnRH receptor system is absent in humans (Morgan et al., 2003). Recent studies have addressed whether type II GnRH receptors are expressed in human breast, endometrial and ovarian cancer cells. The effects of $\mathrm{GnRH}-\mathrm{II}$ on the proliferation of these cells were also investigated (Grundker et al., 2002; Emons et al., 2003). It was demonstrated that type II GnRH receptor mRNA is expressed in these cells and that the antiproliferative effect of $\mathrm{GnRH}-\mathrm{II}$ is more potent than that of $\mathrm{GnRH}-\mathrm{I}$. Furthermore, an ovarian cancer cell line shown to be type II receptor mRNA-positive, but type I receptormRNA-negative, responded to $\mathrm{GnRH}-\mathrm{II}$ and not $\mathrm{GnRH}-\mathrm{I}$. Such studies indicate that these effects are mediated by a GnRH-II-specific receptor. Perhaps the disrupted human type II GnRH receptor gene is able to encode a functional receptor by some as yet unknown mechanism. Certainly, a number of possible mechanisms have been suggested and thoroughly investigated (Morgan et al., 2003). Alternatively, the effects of $\mathrm{GnRH}-\mathrm{Il}$ may be mediated by a distinct cell-surface receptor. Future research will no doubt provide answers to explain these findings. Clearly, the intracellular mechanisms mediating the antiproliferative effects of GnRH analogues on tumour cells are not fully understood. Chen et al. (2002a) demonstrated that $\mathrm{GnRH}-\mathrm{I}$ and $\mathrm{GnRH}-\mathrm{II}$ are over-expressed in cancer cells and inhibit the expression of mRNA encoding the 60S ribosomal phosphoproteins P1 and $\mathrm{P} 2$, which play a key role in the protein translation process. This finding provides a putative mechanism for the direct anti-proliferative effects of $\mathrm{GnRH}$ on cancer cells, whereby reduced expression of P1 and P2 affects the rate of protein translation, thereby decreasing their rate of proliferation.

\section{Effects of GnRH-II on neurones}

The wide distribution of GnRH-II in the central and peripheral nervous systems indicates a neurotransmitterneuromodulatory role. Such a role has been proposed (Millar et al., 2001) based on the occurrence of GnRH-II in frog sympathetic ganglia where it binds high-affinity receptors (Troskie et al., 1997) and potently inhibits M-type $\mathrm{K}^{+}$channels (Jones, 1987; Bosma et al., 1990). GnRH-I and -II genes are co-expressed in human neuroblastoma cell lines (Chen et al., 2001), whereas the immortalized mouse neuronal cell line GT1-7 expresses $\mathrm{GnRH}-\mathrm{I}$, but whether and in what context the peptides are functional as synaptic neurotransmitters in each of these cells is unclear.

\section{GnRH-responsive genes}

The effects of $\mathrm{GnRH}-\mathrm{Il}$ on gene expression in certain types of cell have been addressed using gene array screening technology (Chen et al., 2002b). It has been 
suggested that GnRH-II may interact directly with human and mouse $\mathrm{T}$ cells to trigger gene transcription, and in particular transcription and cell-surface expression of laminin receptor, a $67 \mathrm{kDa}$ protein involved in cell adhesion and migration and in tumour invasion and metastasis (Chen et al., 2002b). More interestingly, it has been demonstrated that a specific type I GnRH receptor antagonist (Cetrorelix) blocked GnRH-I- but not GnRHII-induced effects (Chen et al., 2002b). This finding certainly indicates that the observed effects might be mediated via a GnRH-II-specific receptor. Alternatively, such a result may also be explained by the fact that many antagonists bind to receptors at sites that are distinct from those occupied by agonists. In this scenario, the binding of GnRH-I, known to be an unconformed ligand (Pfleger et al., 2002), would be blocked by antagonist occupation at the type I receptor, but GnRH-II binding, known to be preconformed (Pfleger et al., 2002), would not, as it can occupy a different site on the type I receptor.

\section{GnRH and tissue remodelling}

The invasive ability of trophoblastic cells is known to be modulated by the regulation of their urokinase type plasminogen activator (UPA) and plasminogen activator inhibitor (PAI-1) expression (Lala et al., 2002). It has been reported that $\mathrm{GnRH}-\mathrm{I}$ and -II facilitate the invasion by trophoblasts into the placenta by simultaneously upregulating uPA expression and downregulating PAI-1 expression (Chou et al., 2002). In relation to this, $\mathrm{GnRH}$ regulation of the decidualization process, involving the remodelling of the extracellular matrix of stromal cells by the actions of matrix metalloproteinases (MMPs) and their inhibitors, has also been demonstrated (Chou et al., 2003). In particular, the expression of MMP-2 and MMP-9 and their tissue-specific inhibitors, which play important roles in trophoblast invasion, were shown to be modulated by GnRH (Chou et al., 2003).

\section{Further studies of GnRH-II function}

The DNA sequences of prepro-GnRH-II and type II $\mathrm{GnRH}$ receptor genes and their chromosomal loci enable studies of the patterns of their expression and a preliminary understanding of their evolutionary history. Determining how GnRH-I and GnRH-II bind to and activate $\mathrm{GnRH}$ receptors, and how antagonists such as Cetrorelix modulate peptide binding should be the goals of further structure-function investigations. Attempts to correlate these studies with reproductive physiology or diseases affecting reproductive tissues in mammals are ongoing. Perhaps mouse strains possessing targeted expression of human prepro-GnRH-II or functional type II $\mathrm{GnRH}$ receptor transgenes might be particularly informative in this respect.
This study was supported by The Wellcome Trust (AJP; Grant No. 060257), the Medical Research Council of the UK, the Medical Research Council of South Africa, and the University of Cape Town.

\section{References}

Key references are identified by asterisks.

Acharjee S, Maiti K, Soh JM, Im WB, Seong JY and Kwon HB (2002) Differential desensitization and internalization of three different bullfrog gonadotropin-releasing hormone receptors Molecules and Cells 14101 107

Blomenrohr M, Bogerd J, Leurs R, Schulz RW, Tensen CP, Zandbergen MA and Goos HJ (1997) Differences in structure-function relations between non-mammalian and mammalian gonadotropin-releasing hormone receptors Biochemical and Biophysical Research Communications 238 517-522

Blomenrohr M, Heding A, Sellar R, Leurs R, Bogerd J, Eidne KA and Willars GB (1999) Pivotal role for the cytoplasmic carboxyl-terminal tail of a non-mammalian gonadotropin-releasing hormone receptor in cell surface expression, ligand binding, and receptor phosphorylation and internalization Molecular Pharmacology 56 1229-1237

Bogerd J, Diepenbroek WB, Hund E, van Oosterhout F, Teves AC, Leurs R and Blomenrohr M (2002) Two gonadotropin-releasing hormone receptors in the African catfish: no differences in ligand selectivity, but differences in tissue distribution Endocrinology 143 4673-4682

Bosma MM, Bernheim L, Leibowitz MD, Pfaffinger PJ and Hille B (1990) Modulation of M current in frog sympathetic ganglion cells. In G Proteins and Signal Transduction pp 43-59. The Rockefeller University Press, New York

Chavali GB, Nagpal S, Majumdar SS, Singh O and Salunke DM (1997) Helix-loop-helix motif in GnRH associated peptide is critical for negative regulation of prolactin secretion Journal of Molecular Biology 272731 740

Chen HF, Jeung EB, Stephenson M and Leung PC (1999) Human peripheral blood mononuclear cells express gonadotropin-releasing hormone $(\mathrm{GnRH}), \mathrm{GnRH}$ receptor, and interleukin-2 receptor gamma-chain messenger ribonucleic acids that are regulated by $\mathrm{GnRH}$ in vitro. Journal of Clinical Endocrinology and Metabolism 84 743-750

Chen A, Yahalom D, Laskar-Levy O, Rahimipour S, Ben-Aroya N and Koch Y (2001) Two isoforms of gonadotropin-releasing hormone are coexpressed in neuronal cell lines Endocrinology 142 830-837

*Chen A, Kaganovsky E, Rahimipour S, Ben-Aroya N, Okon E and Koch Y (2002a) Two forms of gonadotropin-releasing hormone $(\mathrm{GnRH})$ are expressed in human breast tissue and overexpressed in breast cancer: a putative mechanism for the antiproliferative effect of $\mathrm{GnRH}$ by downregulation of acidic ribosomal phosphoproteins P1 and P2 Cancer Research 62 1036-1044

Chen A, Ganor Y, Rahimipour S, Ben-Aroya N, Koch Y and Levite M (2002b) The neuropeptides $\mathrm{GnRH}-\mathrm{Il}$ and $\mathrm{GnRH}-\mathrm{I}$ are produced by human T cells and trigger laminin receptor gene expression, adhesion, chemotaxis and homing to specific organs Nature Medicine 8 1421-1426

Cheng CK, Hoo RL, Chow BK and Leung PC (2003) Functional cooperation between multiple regulatory elements in the untranslated exon 1 stimulates the basal transcription of the human $\mathrm{GnRH}-\mathrm{II}$ gene Molecular Endocrinology Epub

Cheon KW, Lee HS, Parhar IS and Kang IS (2001) Expression of the second isoform of gonadotrophin-releasing hormone (GnRH-II) in human endometrium throughout the menstrual cycle Molecular Human Reproduction 7 447-452

Choi KC, Auersperg N and Leung PC (2001) Expression and antiproliferative effect of a second form of gonadotropin-releasing hormone in normal and neoplastic ovarian surface epithelial cells Journal of Clinical Endocrinology and Metabolism 86 5075-5078

Chou CS, Zhu H, Shalev E, MacCalman CD and Leung PC (2002) The effects of gonadotropin-releasing hormone $(\mathrm{GnRH}) \mathrm{I}$ and $\mathrm{GnRH}$ II on the urokinase-type plasminogen activator/plasminogen activator inhibitor system in human extravillous cytotrophoblasts in vitro. Journal of Clinical Endocrinology and Metabolism 87 5594-5603 
Chou CS, Tai CJ, MacCalman CD and Leung PC (2003) Dose-dependent effects of gonadotropin-releasing hormone on matrix metalloproteinase (MMP)-2, and MMP-9 and tissue specific inhibitor of metalloproteinases1 messenger ribonucleic acid levels in human decidual stromal cells in vitro. Journal of Clinical Endocrinology and Metabolism 88 680-688

Davidson JS, Wakefield IK and Millar RP (1994) Absence of rapid desensitization of the mouse gonadotropin-releasing hormone receptor Biochemical Journal 300 299-302

Emons G, Grundker C, Westphalen S, Verschraegen C, Nagy A and Schally AV (2003) GnRH-analogues in ovarian and endometrial cancers. In 7th International Symposium on GnRH Analogues in Cancer and Human Reproduction Amsterdam, The Netherlands

Everest HM, Hislop JN, Harding T, Uney JB, Flynn A, Millar RP and McArdle CA (2001) Signaling and antiproliferative effects mediated by GnRH receptors after expression in breast cancer cells using recombinant adenovirus Endocrinology 142 4663-4672

Finch A, Green L, Hislop J and McArdle CA (2003) Antiproliferative effects of type I and type II GnRH receptors (GnRH-Rs) expressed in breast cancer cells using recombinant adenovirus (Ad). In 7th International Symposium on GnRH Analogues in Cancer and Human Reproduction Amsterdam, The Netherlands

Forrest-Owen W, Willars GB, Nahorski SR, Assefa D, Davidson JS, Hislop J and McArdle CA (1999) The lack of gonadotrophin-releasing hormone $(\mathrm{GnRH})$ receptor desensitisation in alphaT3-1 cells is not due to $\mathrm{GnRH}$ receptor reserve or phosphatidylinositol 4,5-bis-phosphate pool size Molecular and Cellular Endocrinology 147 161-173

Franklin J, Hislop J, Flynn A and McArdle CA (2003) Signalling and anti-proliferative effects mediated by gonadotrophin-releasing hormone receptors after expression in prostate cancer cells using recombinant adenovirus Journal of Endocrinology 176 275-284

Gault PM, Morgan K and Lincoln G (2003) Sheep exhibit novel variations in the organisation of the mammalian type II gonadotropin-releasing hormone receptor gene. In 85th Annual Meeting of The Endocrine Society Philadelphia, USA

Grundker C, Gunthert AR, Millar RP and Emons G (2002) Expression of gonadotropin-releasing hormone II (GnRH-II) receptor in human endometrial and ovarian cancer cells and effects of GnRH-II on tumor cell proliferation Journal of Clinical Endocrinology and Metabolism 87 1427-1430

Heding A, Vrecl M, Hanyaloglu AC, Sellar R, Taylor PL and Eidne KA (2000) The rat gonadotropin-releasing hormone receptor internalizes via a betaarrestin-independent, but dynamin-dependent, pathway: addition of a carboxyl-terminal tail confers beta-arrestin dependency Endocrinology 141 299-306

Hislop JN, Madziva MT, Everest HM, Harding T, Uney JB, Willars GB, Millar RP, Troskie BE, Davidson JS and McArdle CA (2000) Desensitization and internalization of human and xenopus gonadotropin-releasing hormone receptors expressed in alphaT4 pituitary cells using recombinant adenovirus Endocrinology 141 4564-4575

Hislop JN, Everest HM, Flynn A, Harding T, Uney JB, Troskie BE, Millar RP and McArdle CA (2001) Differential internalization of mammalian and non-mammalian gonadotropin-releasing hormone receptors. Uncoupling of dynamin-dependent internalization from mitogen-activated protein kinase signaling Journal of Biological Chemistry 27639685 39694

Jones SW (1987) Chicken II luteinizing hormone-releasing hormone inhibits the M-current of bullfrog sympathetic neurons Neuroscience Letters $\mathbf{8 0}$ 180-184

Kang SK, Tai CJ, Nathwani PS and Leung PC (2001) Differential regulation of two forms of gonadotropin-releasing hormone messenger ribonucleic acid in human granulosa-luteal cells Endocrinology 142 182-192

Krsmanovic LZ, Mores N, Navarro CE, Arora KK and Catt KJ (2003) An agonist-induced switch in $\mathrm{G}$ protein coupling of the gonadotropinreleasing hormone receptor regulates pulsatile neuropeptide secretion Proceedings National Academy of Sciences USA $1002969-2974$
Lala PK, Lee BP, Xu G and Chakraborty C (2002) Human placental trophoblast as an in vitro model for tumor progression Canadian Journal of Physiology and Pharmacology 80 142-149

Lin X, Janovick JA, Brothers S, Blomenrohr M, Bogerd J and Conn PM (1998) Addition of catfish gonadotropin-releasing hormone $(\mathrm{GnRH})$ receptor intracellular carboxyl-terminal tail to rat $\mathrm{GnRH}$ receptor alters receptor expression and regulation Molecular Endocrinology 12 161-171

* Millar R, Lowe S, Conklin D et al. (2001) A novel mammalian receptor for the evolutionarily conserved type II GnRH Proceedings National Academy of Sciences USA 98 9636-9641

Millar RP, Lu Z-L, Pawson AJ, Flanagan CA, Morgan K and Maudsley S Gonadotropin-releasing hormone receptors Endocrine Reviews (in press)

*Morgan K, Conklin D, Pawson AJ, Sellar R, Ott TR and Millar RP (2003) A transcriptionally active human type II gonadotropin-releasing hormone receptor gene homolog overlaps two genes in the antisense orientation on chromosome 1q.12 Endocrinology 144 423-436

Neill JD, Duck LW, Sellers JC and Musgrove LC (2001) A gonadotropinreleasing hormone $(\mathrm{GnRH})$ receptor specific for $\mathrm{GnRH}$ II in primates Biochemical and Biophysical Research Communications 2821012 1018

Okubo K, Mitani H, Naruse K, Kondo M, Shima A, Tanaka M and Aida K (2002a) Conserved physical linkage of GnRH-R and RBM8 in the medaka and human genomes Biochemical and Biophysical Research Communications 293 327-331

Okubo K, Mitani H, Naruse K, Kondo M, Shima A, Tanaka M, Asakawa S, Shimizu N, Yoshiura Y and Aida K (2002b) Structural characterization of GnRH loci in the medaka genome Gene 293 181-189

Pawson AJ, Katz A, Sun YM, Lopes J, Illing N, Millar RP and Davidson JS (1998) Contrasting internalization kinetics of human and chicken gonadotropin-releasing hormone receptors mediated by C-terminal tail Journal of Endocrinology 156 R9-R12

Pawson AJ, Maudsley SR, Lopes J, Katz AA, Sun Y-M, Davidson JS and Millar RP (2003) Multiple determinants for rapid agonist-induced internalization of a non-mammalian gonadotropin releasing hormone receptor: a putative palmitoylation site and threonine-doublet within the carboxyl-terminal tail are critical Endocrinology 144 (in press)

*Pfleger KD, Bogerd J and Millar RP (2002) Conformational constraint of mammalian, chicken, and salmon GnRHs, but not GnRH II, enhances binding at mammalian and nonmammalian receptors: evidence for preconfiguration of GnRH II Molecular Endocrinology 16 2155-2162

Siler-Khodr TM and Grayson M (2001) Action of chicken II GnRH on the human placenta Journal of Clinical Endocrinology and Metabolism 86 804-810

Siler-Khodr TM, Grayson M and Eddy CA (2003) Action of gonadotropinreleasing hormone II on the baboon ovary Biology of Reproduction $\mathbf{6 8}$ 1150-1156

Taylor EW and Agarwal A (1993) Sequence homology between bacteriorhodopsin and G-protein coupled receptors: exon shuffling or evolution by duplication? FEBS Letters 325 161-166

Troskie B, King JA, Millar RP, Peng YY, Kim J, Figueras $\mathbf{H}$ and Illing N (1997) Chicken GnRH II-like peptides and a GnRH receptor selective for chicken GnRH II in amphibian sympathetic ganglia Neuroendocrinology 65 396-402

Wang L, Yoo MS, Kang HM, Im WB, Choi HS, Bogerd J and Kwon HB (2001) Cloning and characterization of cDNAs encoding the GnRH1 and $\mathrm{GnRH} 2$ precursors from bullfrog (Rana catesbeiana). Journal of Experimental Zoology 289 190-201

*White RB, Eisen JA, Kasten TL and Fernald RD (1998) Second gene for gonadotropin-releasing hormone in humans Proceedings National Academy of Sciences USA 95 305-309

Willars GB, Royall JE, Nahorski SR, El-Gehani F, Everest $\mathbf{H}$ and McArdle CA (2001) Rapid down-regulation of the type I inositol 1,4,5-trisphosphate receptor and desensitization of gonadotropinreleasingHormone-mediated $\mathrm{Ca}^{2+}$ responses in alpha T3-1 gonadotropes Journal of Biological Chemistry USA 276 3123-3129 